\title{
LEGAL AND ECONOMIC ENVIRONMENT FOR FOREIGN INVESTMENTS IN BOSNIA AND HERZEGOVINA: ADVANTAGES AND OBSTACLES
}

\author{
Azra Brankovic \\ International University of Sarajevo \\ Emir Sudzuka \\ International University of Sarajevo
}

\begin{abstract}
Investment is one of the most important generators for growth and development of national economies. In case of $\mathrm{B} \& \mathrm{H}$ there is a great need for domestic as well as international investments. Therefore, it is necessary to improve, in the first place, the legal environment including ease of company registration, unification of rules at the state level, simplification of administrative procedures etc. It could attract more domestic and international investors to invest in important projects and to improve overall economical situation in $\mathrm{B} \& \mathrm{H}$. To achieve this goal, it is necessary to meet the essential requirement for successful implementation of various reforms related to macroeconomic stability, financial and technological infrastructure, openness to international trade and transparency of political and legislative environment. The Reform Agenda for Bosnia and Herzegovina was adopted in 2015 and provides, among other things, the creation of conditions and appropriate environment for increase of investments and modernization of the $\mathrm{B} \& \mathrm{H}$ economy, with the aim of economic growth and creation of new jobs. It also assumes strengthening the rule of law, administrative capabilities and increase efficiency in public institutions at all levels of government. In order to contribute to enforcement of this document and to present current advantages and obstacles for investments in Bosnia and Herzegovina, this paper analyzed the provisions of applicable laws relating to foreign investments and economic indicators as a consequence of such legal framework and current position of $\mathrm{B} \& \mathrm{H}$. Research findings indicate that the implementation of the abovementioned structural reforms is a condition sine qua non for increase of foreign direct investments in Bosnia and Herzegovina as well as for its path towards integration with the European Union.
\end{abstract}

Keywords: Foreign Direct Investments; Legal Environment; Economic Growth; Reforms; Reform Agenda; European Union; Bosnia and Herzegovina 


\section{Introduction}

Foreign Investments are an important part of modern economies and legal systems. Domestic firms undertake most investment, but international investment can provide additional advantages beyond its contribution to capital stock. It can serve as a conduit for the local diffusion of technology and expertise, such as through the creation of local supplier linkages and by providing improved access to international markets (OECD, 2015). Foreign investment involves the transfer of tangible or intangible assets from one country to another for the purpose of their use in that country to generate wealth under the total or partial control of the owner of the assets (Sonarjah, 2010). According to the Encyclopedia of Public International Law, it can be also defined as a transfer of funds and materials from one country (called capital-exporting country) to another (called host country) in return for a direct or indirect participation in the earnings of that enterprise.

There have been encouraging trends in development of foreign investments in legal and economic theory. By the end of the century, foreign direct investment was being undertaken by enterprises both large and small with a wide range of concerns. The option of investing in another country has become a normal part of strategic growth plans for enterprises. Individual investors are now seeking investment opportunities outside their own currency region as a matter of course. Moreover, mutual funds make these kinds of investments available to small investors. Investment flows have increased dramatically. For many developing countries, foreign direct investment has become the most important source of capital inflows, overtaking both official development assistance and the funds made available by multilateral development banks. In developing countries, between a third and a half of private corporate investment is undertaken by affiliates of foreign corporations. Investment flows from OECD to non-OECD countries have finally become positive, with large outflows from more developed to less developed markets. Between OECD countries, traditionally the recipients of the largest amounts of foreign investment, the number of enterprises that participate and the range of projects being funded have grown dramatically (Moltke, Konard von, 2000).

Bosnia and Herzegovina has a great need for domestic as well as international investments. The current economic situation is not favorable. There are many reasons for that. The Constitution of Bosnia and Herzegovina was agreed upon in Dayton, specifically in Anex IV of the 
General Framework agreement for Peace in Bosnia and Herzegovina. After the DPA adopted the constitution at the state level, it created a complicated and cumbersome structure with many administrative levels. Power is dispersed between many levels and usually exercised by administrative levels too small to fulfill its functions effectively (Brankovc, 2016).

The minimum number of regulations is enacted at the state level because of the competence of the entities for regulation in this area. Substantive provisions on the status of companies, for example, are at the entity of the Federation of Bosnia and Herzegovina, Republika Srpska and Brcko District. Procedural regulations governing the procedure for establishing the company were also adopted at the entity level, but at national level there is the Framework Law on Registration of Business Entities, which stipulates the obligation of harmonization of procedures in the entities with their procedural rules. An agreement on Stabilization and Association of Bosnia and Herzegovina with the European Union came into force in 2015, and started some reforms with the aim of harmonizing the laws of Bosnia and Herzegovina with the European Union acquis communitarie. This will surely be a long and difficult process due to the absence of a single legal and economic space in Bosnia and Herzegovina. The same is reflected primarily in the fact that competences in very important areas are granted to entities, which results in a large number of laws. Regulations are often different and prevent subjects from setting up the company under the same conditions and operating in the entire territory of Bosnia and Herzegovina (Sudzuka, 2016).

The legal system of Bosnia and Herzegovina in the post-war period and the period of transition is experiencing transformation in different aspects. There is no doubt that the consequences of transition reflect on the economic and legal system of Bosnia and Herzegovina. Along with solving these problems, Bosnia and Herzegovina is trying to follow modern trends in the development of economic and legal systems and to harmonize regulations of various areas with the legislations of developed countries, especially within the integrated regional community, including neighboring countries and the EU member States.

Bosnia and Herzegovina participates in the Stabilization and Association Process and is a potential candidate for EU membership. In December 2014, the EU initiated a new approach to Bosnia and Herzegovina with regards to fulfilling the EU conditions; this led to the signing of enforcement of the Stabilization and Association Agreement on the $1^{\text {st }}$ of June 2015. It replaced the Interim Agreement which had 
been in force since 2008. In February 2016, B\&H submitted the official application for EU membership. Joining the EU will require institutions at the state level to be far more effective than they currently are. Bosnia and Herzegovina has to have strong institutions at the state level with necessary capacity and expertise to deal with the wide range of issues covered by such agreements (Brankovic, 2016).

All these abovementioned issues are closely related to the legal and economic framework for foreign investments in Bosnia and Herzegovina. Investors are interested to have good business climate in the area where they want to invest. Moreover, they are not ready to deal with complicated and long administrative procedures and very strict requirements for conducting business. The country's decentralized government structure creates a complex and multi-layered network of public institutions, administrations and regulations. It is difficult for investors, especially foreign ones, to navigate through this regulatory network, which applies to all aspects of corporate operations, including business registration, licensing and permitting, inspections and direct taxation. This regulatory burden is identified by most observers and as the greatest deterrent to foreign direct investment (UNCTAD, 2015).

This paper will give an overview of the legal framework for foreign investments in Bosnia and Herzegovina with special emphasize on regulations regarding company formation and taxes. Also, the authors will present the advantages of investing in $\mathrm{B} \& \mathrm{H}$ and the current position of investments.

\section{Methodology}

The most important task of this research is the study of current theoretical and practical aspects of the foreign investments as a modern model of financing and improving of modern economies, and their effects on the legal and economic system of Bosnia and Herzegovina.

Therefore, the main hypothesis can be determined as follows: Bosnia and Herzegovina has great potential for attracting and hosting foreign investments due to its favorable geographic position, natural resources and labor force. However, there are also significant obstacles for further economic development: complicated regulatory and administrative system, high rate of corruption in public administration and existence of legal particularism in regulation of different aspects of business at different administrative levels. 
A number of methods will be used in the scientific research, formulation and presentation of the research results in this paper. It is necessary to combine general scientific methods and legal methods that are appropriate for this type of research. In order to realize the objectives of the research and demonstrate the hypotheses, methods for collecting the primary and secondary data will be used.

The method of analysis will interpret in detail the traditional and new approach to the foreign investments, and methods of synthesis will be used for the purpose of concretization of attitudes. The descriptive method will show the results of the research. The statistical method will be used for processing, display and analysis of data obtained in the framework of the primary research conducted. The use of this method will enable the testing and evaluation of the basic hypotheses. The compilation method will show the results of scientific research, observations, opinions and conclusions of other author with due reference to the source.

During the research of this dissertation topic, the normative method will be intensively used in all its forms. In doing so, in first place is the logical-normative method that connects all legal norms relevant to the research of the area. In second place is a formal-normative method that is used to define a hierarchy of sources, according to their legal force in order to systematize the sources that regulate foreign investment law in Bosnia and Herzegovina.

\section{Advantages for Investments in B\&H}

$\mathrm{B} \& \mathrm{H}$ has been trying to attract foreign direct investments because of their importance for the economy of the country, growth, development and solving of unemployment problem. There are many advantages for investing in $\mathrm{B} \& \mathrm{H}$ from the foreign investor's point of view.

The greatest advantage for investing in $\mathrm{B} \& \mathrm{H}$ is its work force. Employees in $\mathrm{B} \& \mathrm{H}$ are well educated, skilled, have high computer literacy, and speak foreign languages. It is easy to find young well educated employees, as well as senior experienced employees, due to the current labor market situation and high unemployment rate in the country. Educated employees in B\&H are much cheaper in comparison with the United States, and the EU countries. Primary research undertaken on Turkish companies which invest in $\mathrm{B} \& \mathrm{H}$, in the frame of the International University project: "Bosnia and Herzegovina's 
commercial relations with Turkey: The Status of B\&H Economy and Recommendations for the future", in the spring of 2016, shows that the main reason for investing in $\mathrm{B} \& \mathrm{H}$ is the availability of educated and cheap labor. A Turkish company from the information and technology field reported that they have established a company in B\&H because of the availability of young, educated people who produce software exclusively for other countries, mainly US and the EU (Ganic \& Brankovic, 2016).

$\mathrm{B} \& \mathrm{H}$ has an abundance of water, energy and raw material. Some Turkish companies in the abovementioned project stated that they invested in $\mathrm{B} \& \mathrm{H}$ due to the availability of relatively cheap and accessible raw materials, electric power and water. Turkish manufacturing companies in $\mathrm{B} \& \mathrm{H}$ reported that raw materials were of high quality, and that there was a very good electrical supply system and an abundance of water (Ganic \& Brankovic, 2016).

B\&H is situated in South East Europe and has an excellent geographic position for foreign investments. Turkish exporting companies in $\mathrm{B} \& \mathrm{H}$ participating in the abovementioned project reported that the position of $\mathrm{B} \& \mathrm{H}$ was very important for them. As they export huge quantities of products to the EU market, the proximity of $\mathrm{B} \& \mathrm{H}$ to the EU was of great importance (Ganic \& Brankovic, 2016).

Foreign investors want to invest in a country where the rule of laws is respected. The signing of the Stabilization and Association Agreement between $\mathrm{B} \& \mathrm{H}$ and the European Union and process of harmonization B\&H's legislation with EU acquis is a clear sign for potential foreign investors that there is safe legal environment to invest in $\mathrm{B} \& \mathrm{H}$.

$\mathrm{B} \& \mathrm{H}$ signed a lot of multilateral and bilateral agreements. Thanks to that, all companies that operate in $\mathrm{B} \& \mathrm{H}$ have the opportunity of exporting to a market of approximately 600 million people without paying any customs duties (FIPA, 2016).

\section{Legal and Economic Environment for Foreign Investments}

B\&H's accelerated Economic Reform Process has contributed significantly to a greatly improved business climate. The aim of $\mathrm{B} \& \mathrm{H}$ is to eliminate legal and administrative obstacles for doing business in $\mathrm{B} \& \mathrm{H}$, as well as to create the most attractive business environment in the South East Europe. The main goal of B\&H is EU membership. Bosnia and Herzegovina is a potential candidate country for EU accession and B\&H has signed the Stabilization and Association Agreement with the European Union, which is a step 
toward EU membership. Bosnia and Herzegovina has signed the Central European Free Trade Agreement (CEFTA), creating a free trade zone with access to a large consumer market. Also, the process of negotiation to join the World Trade Organization is underway (FIPA, 2016).

However, it is necessary to conduct very important reforms in the legal system of Bosnia and Herzegovina, although there is a wellestablished legal environment for foreign investments. In July 2015, the country adopted a Reform Agenda aimed at tackling the difficult socioeconomic situation. Its implementation has started meaningful progress in the implementation of the Reform Agenda necessary for the EU to consider the EU membership application of Bosnia and Herzegovina. Only a strong state can assure economic reforms (Brankovic, 2016).

With regards to the legal environment, there are a few very important fields that should be regulated properly in order to assure an adequate regulatory framework for foreign investments. Besides foreign investments themselves the regulation of company formation, taxation, privatization, concessions, social security contributions etc. are of great importance.

Legislation in the field of foreign investments in $\mathrm{B} \& \mathrm{H}$ includes international sources and sources of domestic law related to the matter. The first group of sources includes multilateral convention which B\&H signed, accepted, and concluded bilateral agreements. The second group of sources includes the Constitution, laws and by-laws in the field of foreign investment (Ganic and Brankovic, 2016. p. 72.).

In the context of domestic legislation, it is important to stress that regulation of foreign investments is well regulated. At the state level they are regulated by the Law on the Policy of Foreign Direct Investments of Bosnia and Herzegovina (hereinafter: LPFDI) published in the Official Gazette of B\&H, 17/98, 13/03, 48/10 and 22/15. The Law on the Policy of Foreign Direct Investment has been in force since 1998. It regulates the basic policies and principles of the participation of foreign investors in the economy of Bosnia and Herzegovina. The law grants foreign investors the same rights and obligations as domestic investors. The following articles of the law (The Law on the Policy of Foreign Direct Investment of Bosnia and Herzegovina, 2015) stressed out the most important rights of foreign investors as follows:

- foreign investors shall be entitled to invest, and to reinvest profits of such investments into any and all sectors of the economy of Bosnia and Herzegovina, and in the same form and under 
the same conditions as defined for the residents of Bosnia and Herzegovina under the applicable laws and regulations of Bosnia and Herzegovina and the Entities and Brcko District of Bosnia and Herzegovina (LPFDI B\&H. a.3)

- Subject to the provisions of this Law, and subject to other laws and treaties of Bosnia and Herzegovina and the laws of entities and Brcko District of Bosnia and Herzegovina, foreign investors shall have the same rights and obligations as the residents of Bosnia and Herzegovina.

- Bosnia and Herzegovina, entities and Brcko District of Bosnia and Herzegovina shall not discriminate with respect to foreign investors in any form, including but not limited to their citizenship, residency, religion, or the state of origin of investment. (LPFDI B\&H. a.8)

- Foreign investors shall have the same property rights in respect to real estate as the citizens and legal entities of Bosnia and Herzegovina (LPFDI B\&H. a. 12)

- The law makes clear that the rights and benefits of foreign investors cannot be terminated or overruled by subsequently passed laws and regulations. The rights and benefits of foreign investors granted and obligations imposed by this Law cannot be terminated or eliminated by the subsequently passed laws and regulations. If such subsequently passed laws and regulations shall have been more favorable to foreign investors, they shall have the right to choose under which regime the respective foreign investment will be governed. (LPFDI B\&H. a. 20)

- Foreign investors shall have the right, for the purposes of their investments, to open accounts on the territory of Bosnia and Herzegovina in any commercial bank denominated in the national or any freely convertible currency. According to article 11 , foreign investors also have the right to transfer abroad income from investments received in the form of profit, dividends, interest, and other forms (LPFDI B\&H. a. 11a).

- Foreign investors are entitled to freely employ foreign nationals, with respect to the labor and immigration laws in B\&H. Subject to the labor and immigration laws in Bosnia and Herzegovina, foreign investors shall have the right to freely employ foreign employees (LPFDI B\&H. a. 14). 
- Foreigninvestorsareprotectedagainst nationalization, expropriation or requisition unless it is a question of the public interest.

- Foreign investment shall notbe subject to any act of nationalization, expropriation, requisition or measures which have similar effects, except in the public interest in accordance with applicable laws and regulations, without any type of discrimination and against the payment of appropriate compensation. (LPFDI B\&H. a. 16a)

- The only limitation to the foreign investment is related to the military equipment and media. Article 4(a) states: Notwithstanding the policy of free admission of foreign direct investment into Bosnia and Herzegovina set forth in Article 3 of this Law, foreign equity ownership of business entity engaged in the production and sale of arms, ammunition, explosives for the military use, military equipment and media shall not exceed $49 \%$ of the equity in that business entity.

There are also laws relating to foreign investments at the entities level. Foreign direct investments are regulated at the level of FB\&H with the Law on Foreign Investments of FB\&H published in Official Gazette of FB\&H No. 61/01, 50/03 and 77/15. In RS it is regulated with the Law on Foreign Investments of RS published in Official Gazette of RS No. 25/02, 24/04, 52/11 and 68/13.

Notwithstanding that this area is well regulated, the problem is that there are too many regulations for such a small country, as a consequence of the constitutional organization.

The legal framework of company formation is also a very important aspect for the overall legal frame of foreign investments. This issue is very specific in Bosnia and Herzegovina due to different competencies of different state levels.

Formal registration of companies has many immediate benefits for the companies and for business owners and employees. Legal entities can outlive their founders. Resources are pooled as several shareholders join forces to start a company. Formally registered companies have access to services and institutions from courts to banks, as well as to new markets. And their employees can benefit from protections provided by the law. An additional benefit comes with limited liability companies. These limit the financial liability of company owners to their investments, so personal assets of the owners are not put at risk. 
Where governments make registration easy, more entrepreneurs start businesses in the formal sector, creating more good jobs and generating more revenue for the government (Doing business, 2016).

The founding, operation, management and termination of businesses in $\mathrm{B} \& \mathrm{H}$ are regulated by the law. The Company Law of the Federation of B\&H published in Official Gazette of FB\&H No. 81/15 regulates such matters in FB\&H and the Company Law of Republic of Srpska published in Official Gazette of RS No. 127/08, 58/09, 100/11 and 67/13 regulate such matters in RS. The current legal framework and regulations are adapted to the international standards applicable in the European Union and other developed market economies.

The following table provides an overview of the basic organizational form of the company according to the current legal framework in $\mathrm{B} \& \mathrm{H}$.

\begin{tabular}{|c|c|c|}
\hline $\begin{array}{l}\text { TYPES OF } \\
\text { COMPANIES }\end{array}$ & $\begin{array}{c}\text { FEDERATION OF BOSNIA AND } \\
\text { HERZEGOVINA }\end{array}$ & REPUBLIC OF SRPSKA \\
\hline $\begin{array}{l}\text { Unlimited } \\
\text { Joint Liability } \\
\text { Company } \\
\text { (d.n.o./o.d.) }\end{array}$ & $\begin{array}{l}\text { Founded by the establishment contract of } \\
2 \text { or more partners, domestic or foreign, } \\
\text { natural persons only; } \\
\text { Founders are liable to use all their assets, } \\
\text { including personal property; } \\
\text { There are no requirements for minimum } \\
\text { or maximum contributions. }\end{array}$ & $\begin{array}{l}\text { Founded by the establishment act of } 2 \text { or } \\
\text { more domestic/ foreign natural and/or } \\
\text { legal partners who commit to do certain } \\
\text { activity under the same company name, } \\
\text { with their own solidary liability for } \\
\text { company commitments; } \\
\text { There are no requirements for minimum } \\
\text { or maximum contributions. }\end{array}$ \\
\hline $\begin{array}{l}\text { Limited } \\
\text { Liability } \\
\text { Company } \\
\text { (d.o.o.) }\end{array}$ & $\begin{array}{l}\text { Founded by the establishment act or } \\
\text { establishment contract by } 1 \text { or more } \\
\text { domestic/foreign natural and/or legal } \\
\text { entities with initial capital divided in parts; } \\
\text { A member in a limited company is liable } \\
\text { for the value of his investment in that } \\
\text { company; } \\
\text { Minimum initial capital is 1,000 BAM } \\
\text { (approx. } 500 \text { EUR). }\end{array}$ & $\begin{array}{l}\text { Founded by the establishment act of } 1 \text { to } 100 \\
\text { domestic/ foreign natural and/or legal entities; } \\
\text { A shareholder in a limited company is } \\
\text { not personally liable for any of the debts } \\
\text { of the company, other than for the value } \\
\text { of his investment in that company; } \\
\text { Monetary part of the basic capital of } \\
\text { Liability Company is 1 BAM (approx } \\
0.50 \text { EUR). }\end{array}$ \\
\hline $\begin{array}{l}\text { Limited } \\
\text { Partnership } \\
\text { (k.d.) }\end{array}$ & $\begin{array}{l}\text { Company founded by the establishment } \\
\text { contract of } 2 \text { or more domestic/foreign } \\
\text { natural and/or legal entities; } \\
\text { There must be at least } 1 \text { partner with full } \\
\text { liability (including private property) and at } \\
\text { least } 1 \text { partner with limited liability, the } \\
\text { liability being limited by the value of his } \\
\text { share in that company. } \\
\text { There are no requirements for minimum } \\
\text { or maximum initial capital. }\end{array}$ & $\begin{array}{l}\text { Founded by the establishment act of } 2 \text { or } \\
\text { more domestic/ foreign natural and/or } \\
\text { legal entities; } \\
\text { One person at least has unlimited } \\
\text { liability for the company, and one person } \\
\text { at least has liability to the amount of his } \\
\text { investment in the company; } \\
\text { There are no requirements for minimum } \\
\text { or maximum initial capital. }\end{array}$ \\
\hline
\end{tabular}




\begin{tabular}{|c|c|c|}
\hline $\begin{array}{l}\text { Joint-Stock } \\
\text { Company } \\
\text { (d.d./a.d.) }\end{array}$ & $\begin{array}{l}\text { Legal entities founded by the establishment } \\
\text { contract of } 1 \text { or more domestic/foreign } \\
\text { natural or legal shareholders with initial } \\
\text { capital divided into shares; } \\
\text { 1. Open joint-stock company is a legal } \\
\text { entity (banks, insurance companies, or } \\
\text { companies with minimum initial capital } \\
\text { of } 4 \text { mil BAM (approx. } 2 \text { mil EUR) and } 40 \\
\text { shareholders at least), whose shares may } \\
\text { be publicly listed; } \\
\text { 2. Closed joint-stock company is a legal } \\
\text { entity whose shares are distributed among } \\
\text { a limited number of shareholders. The } \\
\text { minimum initial capital is 50,000 BAM } \\
\text { (approx. } 25,000 \text { EUR). }\end{array}$ & $\begin{array}{l}\text { Legal entities founded by the establishment } \\
\text { contract of } 1 \text { or more domestic/foreign } \\
\text { natural and/or legal entities with initial } \\
\text { capital divided into a defined number of } \\
\text { shares; } \\
\text { 1. Open joint-stock company is a legal } \\
\text { entity whose shares may be publicly } \\
\text { traded, i.e. offers its shares for sale upon } \\
\text { the open market and they are listed on the } \\
\text { stock exchange and other public markets. } \\
\text { Minimum initial capital is } 50,000 \text { BAM } \\
\text { (approx. } 25,000 \text { EUR). } \\
\text { 2. Closed joint-stock company is a legal } \\
\text { entity whose shares are distributed } \\
\text { among a limited number of shareholders. } \\
\text { Minimum initial capital is } 20,000 \text { BAM } \\
\text { (approx. } 10,000 \text { EUR). }\end{array}$ \\
\hline
\end{tabular}

Table 1. Types of companies in B\&H

Source: FIPA, 2016

In harmonizing the laws of Bosnia and Herzegovina with EU legislation in the field of company law, as the initial phase, freedom of establishment is the most important area (SAA, art. 50-57.) It is one of the most important categories of company law in the European Union bearing in mind that represents a conditio sine qua non for the free movement of people, goods, capital and services. The right of establishment of natural and legal persons constitutes a legal basis for the free exercise of commercial activities on the territory of EU member states. This involves the pursuit of economic activities through an existing company or performance of such activities through the establishment of new companies. Freedom of establishment assumes that all forms of restrictions and discrimination are abolished by introducing the so-called national treatment for established companies, before the establishment of the European Union as well as the introduction of obligations phasing out of national law in the transitional period.

According to Professor Horak, establishment means the right of legal or natural persons who are nationals of a Member State of the European Union to establish a legal person or company in the territory of a Member State that is not his own, and includes the initiation and performance of independent activities. The definition of freedom of establishment resulting from the Treaty on Functioning of EU and is part of the freedom to provide services (Horak, 2013).

The legal basis for the harmonization of company law is contained in the provisions of the primary legislation of the European Union. 
Company laws are incorporated primarily in the corpus of national law. Analyzing the attitude of European and national legislations, one should keep in mind several factors with regards to that national law, not only regulations, but also the case law and doctrine. Given that the matter of company law is not a static category, there is a need for continued convergence and harmonization of national law in order to achieve market freedoms, in particular freedom of establishment and movement of capital in the internal market of the EU.

In the case of Bosnia and Herzegovina, it is not easy to achieve this harmonization because of the existence of regulations on different administrative levels. That is not a problem only for approximation and accession to EU but also for all other potential and interested foreign investors.

According to the applicable laws in $\mathrm{B} \& \mathrm{H}$, beside formation of a subsidiary company, foreign entities can establish a Representative Office in $\mathrm{B} \& \mathrm{H}$ for performing market research, informative and promotional activities and for its own representation. The Representative Office does not have the status of a legal entity, i.e. the Representative Office cannot conclude agreements on behalf its founder, except representative offices of foreign air transportation companies which can sell transportation documents in accordance with bilateral agreements and international conventions signed by B\&H. The Representative Office becomes operational after entering into the Register of Foreign Representative Offices kept by the Ministry of Foreign Trade and Economic Relations with B\&H.

The business environment in B\&H has significantly improved in recent years. A set of new economic laws in B\&H were adopted in accordance with EU standards. B\&H has a well-established economic environment for foreign investment. B\&H is a financially stable country, with privatization possibilities in strategic sectors, a well regulated tax system, free trade zones, and other various measures to support and facilitate in foreign investment (Ganic, M., Brankovic, A. 2016).

Recognizing the importance of creating a favorable business environment to attract investment, and given the increasing competition when it comes to attracting FDI, below, we provide an overview of the relevant legislation regulating the legal and financial environment, and tax system and employment legislation related to foreign investments in $\mathrm{B} \& \mathrm{H}$ : 


\section{Laws Related to Investment and Business:}

- Cleansed text of the Law on the Policy of Foreign Direct Investment of BiH (Official Gazette of BiH No. 17/98, 13/03, 48/10 and 22/15)

- Law on Foreign Investments of RS (Official Gazette of RS No. 25/02, $24 / 04,52 / 11$ and $68 / 13$ )

- Cleansed text of the Law on Foreign Investments of FBiH (Official Gazette of FBiH No. 61/01, 50/03 and 77/15)Company Law of the $\mathrm{FBiH}$ (Official Gazette of FBiH No. 81/15)

- Company Law of the RS (Official Gazette of RS No. 127/08, 58/09, $100 / 11$ and 67/13)

\section{Laws Related to Taxes}

- Law on Value Added Tax of BiH (Official Gazette of BiH No. 09/05, $35 / 05$ and 100/08)

- Instruction on Conditions for and Methods of VAT Refund to Foreign Persons of BiH (Official Gazette of BiH No. 01/07)

- Law on Corporate Income Tax of FBiH (Official Gazette of FBiH No. 15/16)

- Law on Corporate Income Tax of RS (Official Gazette of RS No. 95/15)

\section{Laws Related to Free Zones}

- Law on Free Trade Zones of BiH (Official Gazette of BiH No. 99/09)

- Law on Free Zones of RS (Official Gazette of RS No. 65/03)

- Law on Free Zones of FBiH (Official Gazette of FBiH No. 2/95, 37/04 and 43/04)

\section{Laws Related to Business Registration}

- Framework Law on Registration of Business Entities of BiH (Official Gazette of BiH No. 42/04)

- Excerpt from the Law on Registration of Business Entities of RS (Official Gazette of RS No. 67/13 and 15/16)

- Law on Registration of Business Entities of FBiH (Official Gazette of FBiH No. 27/05. 68/05, 43/09 and 63/14) 
- Excerpt from the Decision on Establishment and Work of Foreign Representative Offices of $\mathrm{BiH}$ (Official Gazette of $\mathrm{BiH}$ No. 15/03)

\section{Laws Related to Employment:}

- Labour Law of FBiH (Official Gazette of FBiH No. 26/16)

- Labour Law of RS (Official Gazette of RS No. 1/16)

- Law on foreigners of BiH (Official Gazette od BiH No. 88/15)

This list shows that the most of the areas relevant for foreign investments are regulated with two or more laws which are in most cases similar, but not completely equal. In the theory of law, this is called legal particularism and pluralism. This phenomenon is undesirable because it makes starting and conducting business for foreign investors very complicated. Therefore it is necessary, among all other reforms, to perform a constitutional reform in order to ensure safe place and legal environment like in other EU member states and to attract as much foreign investors as possible. That is for sure the only path for development of $\mathrm{B} \& \mathrm{H}$ economy and overall conditions for the normal life of its citizens.

\section{Current Position of B\&H - Data Presentation and Analysis}

The 2016 Doing Business ${ }^{1}$ report ranks B\&H $79^{\text {th }}$ out of 189 economies that were included in the rankings. Data for Ease of doing business shows that business rank of $\mathrm{B} \& \mathrm{H}$ has been decreasing over the period 2012 - 2014. The business situation improved in 2015 and continued improving in the year 2016. The rank in 2016 improved 3 positions compared to the previous year. (see Figure 1. on next page)

In order to better understand the position of $\mathrm{B} \& \mathrm{H}$ regarding business regulations, it is necessary to analyze the components of Ease of doing business. There are ten following components: Starting a business; Dealing with Construction Permits; Getting Electricity; Registering Property; Getting Credit; Protecting Minority Investors; Paying taxes; Trading across the borders; Enforcing Contracts; Resolving Insolvency.

The ranking of the components of "Ease of doing business" for B\&H are presented in Figure 2. on next page.

1) The Doing Business project is World Bank group's project that provides objective measures of business regulations and their enforcement in 189 economies. 


\section{Doing Business Rank in B\&H}

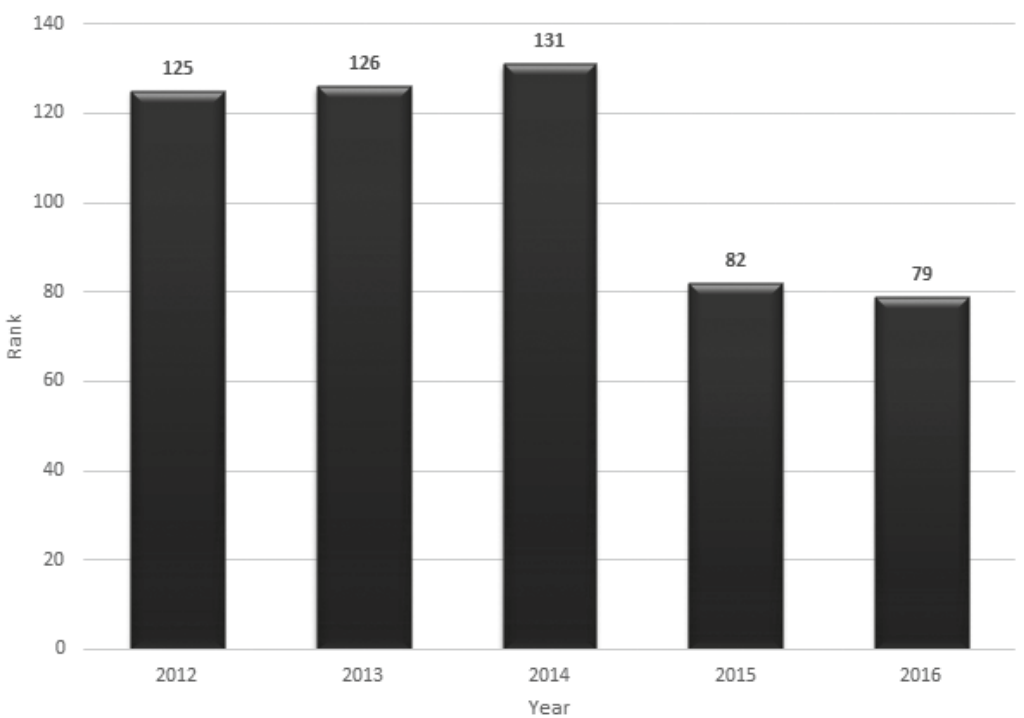

Figure 1: Doing Business rank in B\&H

Source: Author's elaboration on World Bank Group Data, 2016

\section{Components of Ease of Doing Business - Ranked}

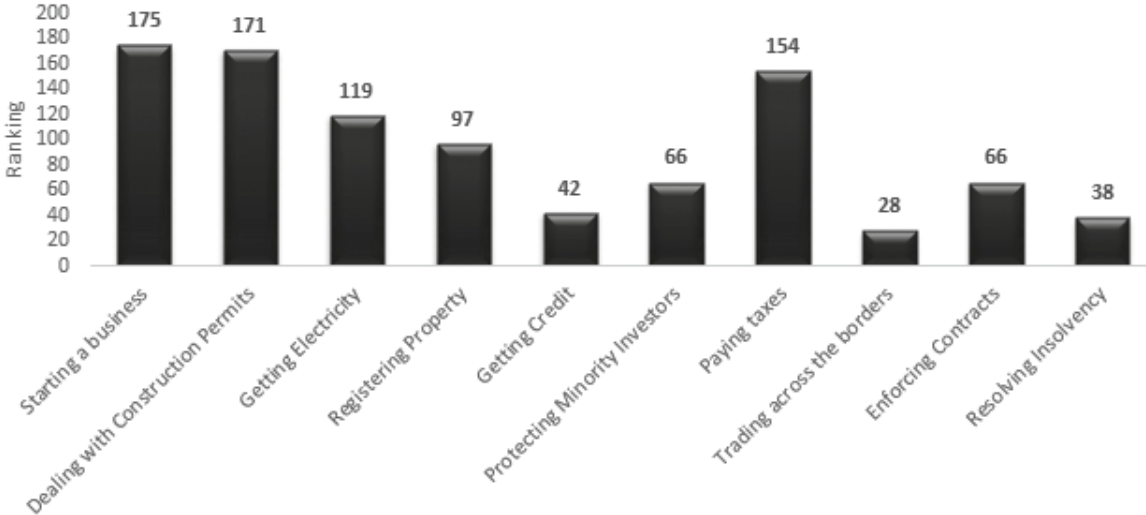

Figure 2: Components of Ease of doing Business - Ranked

Source: Author's elaboration on World Bank Group Data, 2016

The ranking of the components of "Ease of doing business" shows quite a different picture in comparison to the general rank. The worst situation is in the area of starting a new business. B\&H is ranked $175^{\text {th }}$ out of 189 countries regarding the start of new business. It is ten positions worse compared to the previous year. 
Starting a business in $\mathrm{B} \& \mathrm{H}$ requires more time, money, capital and procedures than in many countries in EU and Central Asia. (see Table 2. below).

\begin{tabular}{|l|c|c|c|}
\hline \multicolumn{1}{|c|}{ Indicator } & B\&H & EU\&Central Asia & OECD high income \\
\hline Procedures (number) & 12 & 4.7 & 4.7 \\
\hline Time (days) & 67 & 10 & 8.3 \\
\hline Cost (\% of income per capita) & 14.8 & 4.8 & 3.2 \\
\hline $\begin{array}{l}\text { Paid-in min. capital } \\
\text { (\% of income per capita) }\end{array}$ & 28 & 3.8 & 9.6 \\
\hline
\end{tabular}

Table 2. Starting a business in B\&H

Source: World Bank group, 2016

It is interesting to note that all countries of ex-Yugoslavia have a better rank than $B \& H$. Serbia is on the $59^{\text {th }}$ position, Montenegro on the $46^{\text {th }}$ position, Croatia on the $40^{\text {th }}$, Slovenia is $29^{\text {th }}$ and Macedonia is $12^{\text {th }}$. These countries have similar competitive advantages to B\&H. They all have a well-educated workforce, raw materials, water and energy. They all have an excellent geographical position, similar to B\&H. They are either members of the EU like Slovenia and Croatia or well advanced toward EU integration compared to B\&H. Taking all this into account, $\mathrm{B} \& \mathrm{H}^{\prime}$ priority should be to make reforms and improve its legal and economic environment for foreign direct investment.

\section{Conclusion}

$\mathrm{B} \& \mathrm{H}$ needs international investments in order to solve its economic problems, huge unemployment and enhance economic growth and development. There are many advantages for investing in $\mathrm{B} \& \mathrm{H}$. In the first place, it is its well-educated and cheap work force, with language and computer skills. There is an abundance of raw material, water and energy. B\&H's favorable geographic position, many bilateral and multilateral agreements, as well as advancement toward the EU make $\mathrm{B} \& \mathrm{H}$ a desirable destination for foreign direct investments.

However, there are also obstacles for foreign direct investments. The country's decentralized government structure creates a complex and multi-layered network of public institutions, administrations and regulations. It is difficult for investors, especially foreign ones, to 
navigate through this regulatory network, which applies to all aspects of corporate operations, including business registration, licensing and permitting, inspections and direct taxation. Because of all these problems, $\mathrm{B} \& \mathrm{H}$ is ranked on the $79^{\text {th }}$ position in World Bank's "Doing business" project, well behind neighboring countries that have similar comparative advantages to $\mathrm{B} \& \mathrm{H}$.

It is necessary for $\mathrm{B} \& \mathrm{H}$ to improve, in the first place, its legal environment, including ease of company registration, unification of rules at the state level and simplification of administrative procedures. The phenomenon of legal particularism exists in $\mathrm{B} \& \mathrm{H}$. It is undesirable because it makes starting and conducting business for foreign investors very complicated. Therefore it is necessary, among all other reforms, to perform a constitutional reform in order to ensure safe place and legal environment like in other EU member states and to attract as much foreign investors as possible. The Reform Agenda for Bosnia and Herzegovina was adopted in 2015 and should provide the appropriate environment for increase of investments and modernization of the $\mathrm{B} \& \mathrm{H}$ economy, with the aim of economic growth and creation of new jobs. It also assumes to strengthen the rule of law, administrative capabilities and increase efficiency in public institutions at all levels of government.

\section{References}

Brankovic, A. (2016). Administrative Structure of Bosnia and Herzegovina, in Yucel Ogurlu and Ahmed Kulanic (eds), Bosnia and Heryegovina: Law, Society and Politics, International University of Sarajevo

DOING BUSINESS, (2016). Measuring Regulatory Quality and Efficiency, Economy Profile 2016, Bosnia and Herzegovina http://www.doingbusiness. org/data/exploreeconomies/bosnia-and-herzegovina/ /media/giawb/ doing\%20business/documents/profiles/country/BIH.pdf

FIPA (2016). Investment Opportunities in Bosnia and Herzegovina, http://www. fipa.gov.ba/publikacije_materijali/brosure/io_24.03.2016.pdf

Ganic, M. and Brankovic, A. (2016). Bosnian and Herzegovinian's commercial relations with Turkey: The Status of B\&H Economy and Recommendations for the future, International University of Sarajevo;

Horak, H. (2013). Sloboda poslovnog nastana trgovackih drustava u pravu Europske Unije, Ekonomski fakultet Zagreb.

OECD (2015), Policy Framework for Investment 2015 Edition, OECD Publishing, Paris. http://dx.doi.org/10.1787/9789264208667-en 
Sonrajah, M. (2010). The International Law of Foreign Investment, $3^{\text {rd }}$ ed., Cambridge University Press.

Stabilization and Association Agreement (2008). http://europa.ba/wp-content/ uploads/2015/05/delegacijaEU_2011121405063686eng.pdf

Sudzuka, E. (2016). Europeisation of Bosnian and Herzegovinian Company Law in the Absence of a Unique Legal and Economic Environment, conference paper, Europeization of Croatian Private Law, Faculty of Law Split.

UNCTAD (2015). Investment Policy Review -Bosnia and Herzegovina, http://unctad.org/en/PublicationsLibrary/diaepcb2015d1_en.pdf 